\title{
Investigation of Photophysical Properties of Ceric Ammonium Nitrate Mediated Oxidative Dimerization of 1-Methoxynaphthalene and 4,4'-Diamino-1,1'- dimethoxy-2,2'-binaphthyl
}

\section{J. RAMCHANDER}

Department of Chemistry, Nizam College, Osmania University, Hyderabad-500001, Telangana State, India

ramorgchemou@gmail.com

Received 26 December 2015 / Accepted 20 January 2016

\begin{abstract}
The absorption and fluorescence properties of structurally correlated compound are 1,1'dimethoxy-4,4'-dinitro-2,2'-binaphthyl and 4,4'-diamino-1,1'-dimethoxy-2,2'-binaphthyl in 9 various solvents of different polarities was studied. The absorption maxima of these compounds not follow the selectivity with respect to the solvent polarity, whereas depends on the nature of substitution. The fluorophores with electron withdrawing group have larger fluorescence quantum yields and greater solvatochromism than the compounds with electron donating groups. Protic solvents yielded higher fluorescence quantum efficiency.
\end{abstract}

Keywords: Solvatochromism, Emission, Stokes shift, Chromophore, Fluorophore

\section{Introduction}

Intensive investigations on materials for the developments of artificial photosynthetic, light energy conversion devices, photoconducting and organic-inorganic nano composite systems are being carried out by different workers in the field of photochemistry ${ }^{1-12}$. This study explains the technological importance especially for constructing light emitting diodes (LEDs), photovoltaic cells, organic solar cells and artificial or model photosynthetic devices, etc $^{13-17}$. Generally, $p$-extended compounds in which the nitro group is introduced directly into the fluorophore show very weak fluorescent as compared to unsubstituted compounds, since the nitro group elongates the path for internal conversion immediately after intersystem crossing ${ }^{18-22}$. The fluorescence of nitro compound was investigated by Ajro Hachia et al., ${ }^{23}$. The electronic absorption and emission studies revealed that the light absorbing and emitting chromophore is the naphthoxy moiety. There is no extensive delocalization of aromatic $\pi$-electrons in the active chromophore which exhibited lower quantum yields and lower Stokes shifts ${ }^{24}$. Fluorophores with electron withdrawing group have larger fluorescence quantum yields and greater 
solvatochromism than the compounds with electron donating groups. Protic solvents yielded higher fluorescence quantum efficiency ${ }^{25}$. The nitro group was inserted into the naphthalene moiety at $\mathrm{C} 4$ position and it acts as acceptor. However, $\mathrm{C} 1$ position methoxy groups attached then it acts donating nature. Based on the importance of substituted naphthalene derivatives in the field of environmental fluorescent sensors we are interested in the investigation of photophysical properties of a few substituted naphthalenes and we report the electronic absorption and emission properties of methoxynitro naphthalene (2), 1,1'-dimethoxy -4,4'-dinitro-2,2'-binaphthyl (3) and 4,4'diamino-1,1'-dimethoxy-2,2'-binaphthyl (4).

\section{Experimental}

Spectroscopic grade organic solvents were obtained from Finar Chemicals. Starting and other chemicals and reagents were purchased from Sigma-Aldrich unless otherwise stated and were used without further purification. UV-Vis spectra were recorded on Elico SL 159 UV-Vis spectrophotometer. Steady state fluorescence was investigated on Shimadzu RF-5301PC spectrofluorophotometer with $5 \mathrm{~nm}$ excitation and emission slit width at $25{ }^{\circ} \mathrm{C}$ employing $1 \mathrm{~cm}$ path length quartz cell. The relative fluorescence quantum yield, $\Phi$ was evaluated by employing Eq. 1 .

$$
\Phi_{s t d}=\Phi_{u n k}\left(\frac{I_{u n k}}{I_{s t d}}\right)\left(\frac{A_{s t d}}{A_{u n k}}\right)\left(\frac{n_{u n k}}{n_{s t d}}\right)^{2}
$$

Where $\Phi, \Phi_{\text {std, }} \mathrm{I}_{\text {unk }}, \mathrm{I}_{\text {std }}, \mathrm{A}_{\text {std }}, \mathrm{A}_{\text {unk }}, \mathrm{n}_{\text {unk }}$ and $\mathrm{n}_{\text {std }}$ are fluorescence quantum yields, integral of the emission intensities, the absorbance at the excitation wavelength and refractive indexes of the corresponding solvents of the unknown samples and the standard, respectively. 9,10- Diphenyl anthracene was used as standard in cyclohexane solvent $(0 . \Phi=9)$.

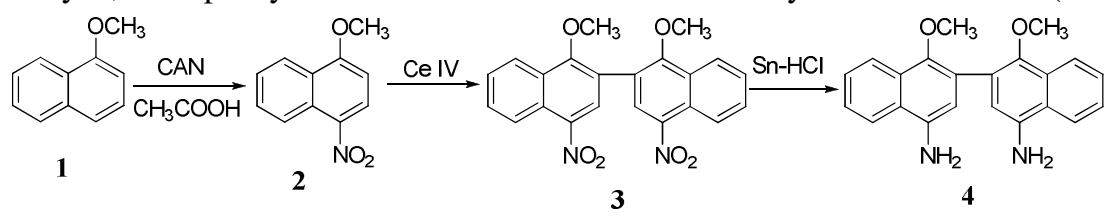

Scheme 1. Synthesis of 4,4'-diamino-1,1'-dimethoxy-2,2'-binaphthyl(4)

General procedure for the synthesis of 4,4'-diamino-1,1'-dimethoxy-2,2'binaphthyl $(\mathbf{4})^{26}$

In a $50 \mathrm{~mL}$ round bottom flask fitted with a reflux condenser, $1 \mathrm{~g}$ of 1,1'-dimethoxy-4,4'dinitro-2,2'-binaphthyl, $2 \mathrm{~g}$ of granulated tin and $10 \mathrm{~mL}$ of conc. $\mathrm{HCl}$ in three equal portions were placed with stirring after each addition. The reaction mixture was heated on an oil bath at $140{ }^{\circ} \mathrm{C}$ for $1 \mathrm{~h}$. the reaction mixture was cooled to room temperature and poured into crushed ice, neutralized with $25 \%$ aqueous $\mathrm{NaOH}$ solution. The precipitate was filtered and dissolved in ethyl acetate. The reduced amino product was collected after the removal of ethyl acetate in vacuum. The pure compound was obtained as orange-red color.

\section{Results and Discussion}

\section{Electronic spectral study of oxidative dimerization of 1-methoxy naphthalene}

The photophysical properties of naphthalene and its derivatives have been explored in order to understand the fate of organic molecule in the excited state, change in the dipole moment, and spin multiplicity. The title compounds are naphthalene derivatives and are fluorescing, therefore 
we have investigated their fluorescent properties. The electronic absorption spectra of 1,1dimethoxy-4,4'-dinitro-2,2'-binaphthyl (3), 1-methoxy-4-nitronapthalene (2) are shown in Figure 1 and 2 in benzene and 1,2-dichloroethane respectively at $20{ }^{\circ} \mathrm{C}$. Compound 2 exhibited an absorption maxima at $356 \mathrm{~nm}$ along with an absorption doublet maxima at $260 \mathrm{~nm}$. Similar absorption spectra were obtained in other solvents shown in Table 1. The electronic absorption data of compound $\mathbf{3}$ and compound $\mathbf{4}$ was evaluated in all the solvents that were employed for the compound 2 and the data is tabulated in Tables 2 and 3 respectively. From the table it can be understand that the absorption maxima bear no linear relationship with the polarity of the solvent but are solvent specific. However all the three compounds investigated in the prototropic solvents, in methanol the absorption maxima occurred at longer wavelength then in isopropanol and ethanol.

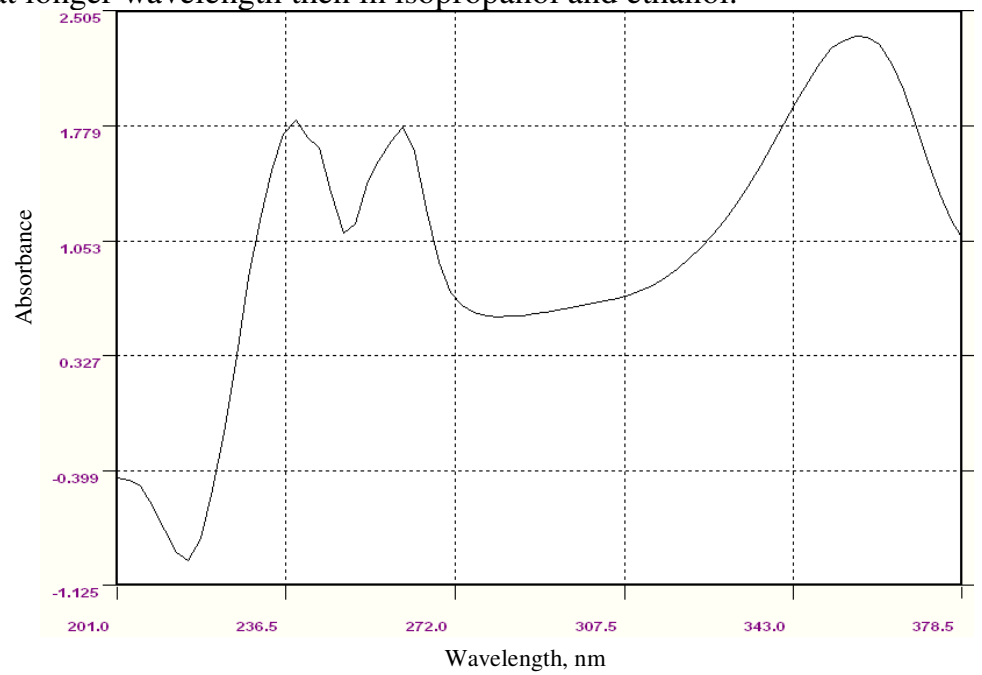

Figure 1. The electronic absorption spectrum of 1-methoxy-4-nitronaphthalene (2) $\left[8.2 \times 10^{-5}\right]$ in DCE

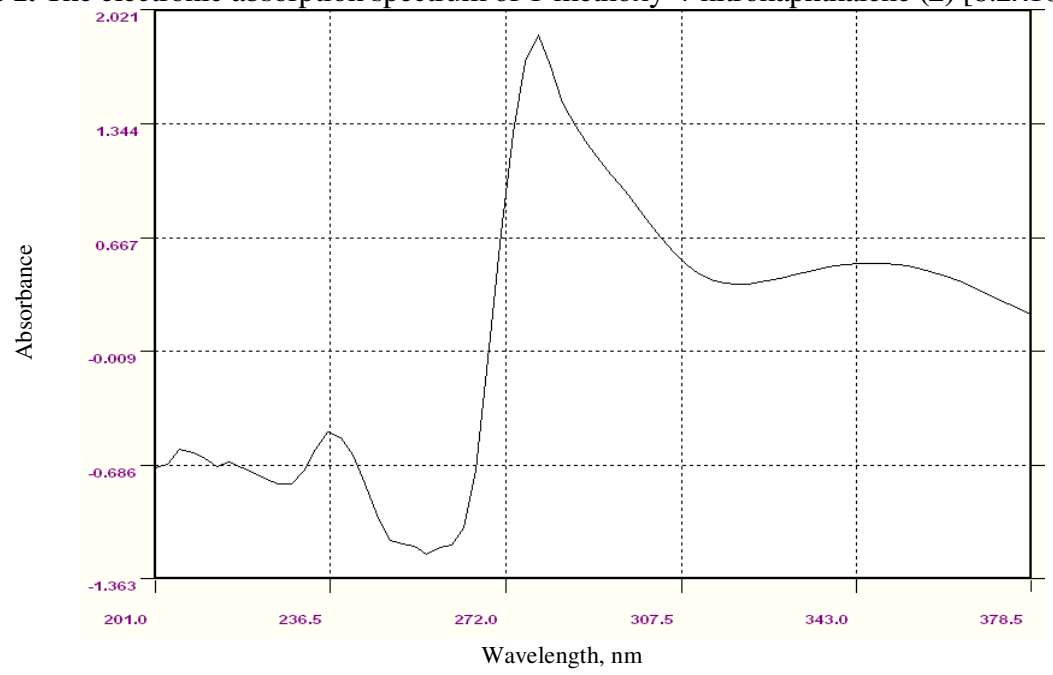

Figure 2. The electronic absorption spectrum of 1,1'-dimethoxy -4,4'-dinitro-2,2'-binaphthyl (3) $\left[4.12 \times 10^{-5}\right]$ in benzene 
The Tables 1, 2 and 3 reveal interestingly structural and steric dependent absorption spectra. Compound $\mathbf{2}$ is a monomeric unit with electron donating and electron withdrawing groups at complimentary position while compound $\mathbf{3}$ is a dimer of $\mathbf{2}$ maintains the donating and withdrawing groups locations. But the absorption maxima of $\mathbf{3}$ in a given solvent always occurred at lower wavelength than compound 2 . The occurrence of absorption maxima at lower wavelength for the dimer is probably explained due to steric factor i:e delocalization of $n$-electron and $\pi$ electrons in $\mathbf{3}$ is partially hindered by bulky naphthalene ring at ortho position while there is no such hindrance found in $\mathbf{2}$. Compound $\mathbf{4}$ is reduced form of $\mathbf{3}$. When nitro group is reduced to amino group as in $\mathbf{4}$ there is no extensive delocalization of $n$ and $\pi$ electrons, there by absorbing at lower wavelength than 3. Hence the order of low energy absorption maxima in the compounds is $\mathbf{2}>\mathbf{3}>\mathbf{4}$.

\section{Fluorescence}

The steady state fluorescence spectra of $\mathbf{4 , 3}$ and $\mathbf{2}$ is shown in Figure 3 in dichloroethane. Similar spectra were obtained for remaining solvents and the fluroscence data obtained is shown in Table 1, 2 and 3.

Table 1. Spectral characteristics of 1-methoxy-4-nitronaphthalene (2)

\begin{tabular}{|c|c|c|c|c|c|c|}
\hline $\begin{array}{l}\stackrel{0}{z} \\
\dot{n}\end{array}$ & Solvent & $\begin{array}{l}\text { Solvent Polarity } \\
\text { (dielectric } \\
\text { constant) }\end{array}$ & $\begin{array}{c}\lambda_{\text {abs } \cdot \max (\mathrm{nm})} \\
\left(\epsilon, \mathrm{dm}^{2} \mathrm{~mol}^{-1}\right)\end{array}$ & 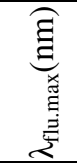 & 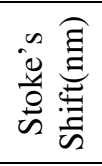 & $\Phi_{\mathrm{f}}$ \\
\hline 1 & Cyclohexane & 2.02 & $341\left(1.34 \times 10^{4}\right)$ & 450 & 109 & $4.1 \times 10^{-2}$ \\
\hline 2 & Benzene & 2.28 & $351\left(8.6 \times 10^{3}\right)$ & 450 & 99 & $8.9 \times 10^{-2}$ \\
\hline 3 & Chloroform & 4.81 & $361\left(2.84 \times 10^{4}\right)$ & 444 & 83 & $6.5 \times 10^{-2}$ \\
\hline 4 & 1,2-Dichloroethane & 10.42 & $356\left(1.63 \times 10^{4}\right)$ & 466 & 110 & $3.46 \times 10^{-1}$ \\
\hline 5 & Ethanol & 25.3 & $351\left(2.23 \times 10^{4}\right)$ & 453 & 102 & $1.74 \times 10-1$ \\
\hline 6 & 2-Propanol & 20.80 & $351\left(2.44 \times 10^{4}\right)$ & 450 & 99 & $1.27 \times 10^{-1}$ \\
\hline 7 & Methanol & 33.00 & $354\left(1.73 \times 10^{4}\right)$ & 452 & 98 & $2 \times 10^{-2}$ \\
\hline 8 & Acetonitrile & 36.64 & $356\left(2.29 \times 10^{4}\right)$ & 449 & 93 & $2.25 \times 10^{-2}$ \\
\hline 9 & DMF & 38.25 & $359\left(1.5 \times 10^{4}\right)$ & 472 & 113 & $1.79 \times 10^{-1}$ \\
\hline
\end{tabular}

Table 2. Spectral characteristics of 1,1'-dimethoxy -4,4'-dinitro-2,2'-binaphthyl (3)

\begin{tabular}{|c|c|c|c|c|c|c|}
\hline $\begin{array}{l}\stackrel{0}{z} \\
\dot{n}\end{array}$ & Solvent & $\begin{array}{l}\text { Solvent Polarity } \\
\text { (dielectric } \\
\text { constant) }\end{array}$ & $\begin{array}{c}\lambda_{\text {abs } \cdot \max (n m)} \\
\left(€, \mathrm{dm}^{2} \mathrm{~mol}^{-1}\right)\end{array}$ & 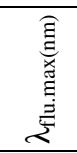 & 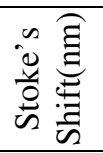 & $\Phi_{\mathrm{f}}$ \\
\hline 1 & Cyclohexane & 2.02 & $341\left(8 \times 10^{3}\right)$ & 450 & 109 & $6.65 \times 10^{-2}$ \\
\hline 2 & Benzene & 2.28 & $346\left(1.3 \times 10^{4}\right)$ & 478 & 132 & $5 \times 10^{-2}$ \\
\hline 3 & Chloroform & 4.81 & $351\left(1.52 \times 10^{4}\right)$ & 466 & 115 & $1.57 \times 10^{-1}$ \\
\hline 4 & 1,2-Dichloroethane & 10.42 & $351\left(1.64 \times 10^{4}\right)$ & 463 & 112 & $4.2 \times 10^{-1}$ \\
\hline 5 & 2-Propanol & 20.80 & $344\left(2 \times 10^{4}\right)$ & 440 & 96 & $8 \times 10^{-2}$ \\
\hline 6 & Ethanol & 25.3 & $344\left(1.72 \times 10^{4}\right)$ & 436 & 92 & $3 \times 10^{-1}$ \\
\hline 7 & Methanol & 33.00 & $346\left(1.14 \times 10^{4}\right)$ & 422 & 76 & $1.94 \times 10^{-2}$ \\
\hline 8 & Acetonitrile & 36.64 & $349\left(1.8 \times 10^{4}\right)$ & 466 & 117 & $3.85 \times 10^{-2}$ \\
\hline 9 & Dimethylformamide & 38.25 & $351\left(1.4 \times 10^{4}\right)$ & 468 & 117 & $3.21 \times 10^{-1}$ \\
\hline
\end{tabular}


Table 3. Spectral characteristics of 4,4'-diamino-1,1'-dimethoxy-2,2'-binaphthyl (4)

\begin{tabular}{|c|c|c|c|c|c|c|}
\hline$\stackrel{0}{z}_{i}$ & Solvent & $\begin{array}{l}\text { Solvent Polarity } \\
\text { (dielectric } \\
\text { constant) }\end{array}$ & $\begin{array}{c}\lambda_{\mathrm{abs} \cdot \max (\mathrm{nm})} \\
\left(\epsilon, \mathrm{dm}^{2} \mathrm{~mol}^{-1}\right)\end{array}$ & 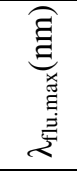 & 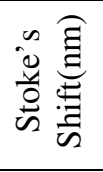 & $\Phi_{\mathrm{f}}$ \\
\hline 1 & Cyclohexane & 2.02 & $339\left(4.26 \times 10^{3}\right)$ & 451 & 112 & $2.89 \times 10^{-1}$ \\
\hline 2 & Benzene & 2.28 & $339\left(6 \times 10^{3}\right)$ & 478 & 139 & $2.56 \times 10^{-1}$ \\
\hline 3 & Chloroform & 4.81 & $339\left(6 \times 10^{3}\right)$ & 445 & 106 & $4.5 \times 10^{-1}$ \\
\hline 4 & 1,2-Dichloroethane & 10.42 & $336\left(5.8 \times 10^{3}\right)$ & 464 & 128 & $5.85 \times 10^{-1}$ \\
\hline 5 & 2-Propanol & 20.80 & $339\left(4.22 \times 10^{3}\right)$ & 448 & 109 & $5.8 \times 10^{-1}$ \\
\hline 6 & Ethanol & 25.3 & $336\left(6.5 \times 10^{3}\right)$ & 437 & 101 & $6.6 \times 10^{-1}$ \\
\hline 7 & Methanol & 33.00 & $339\left(3.6 \times 10^{3}\right)$ & 424 & 85 & $2.1 \times 10^{-1}$ \\
\hline 8 & Acetonitrile & 36.64 & $339\left(4.8 \times 10^{3}\right)$ & 449 & 110 & $5.47 \times 10^{-1}$ \\
\hline 9 & Dimethylformamide & 38.25 & $349\left(3.84 \times 10^{3}\right)$ & 463 & 114 & $4.4 \times 10^{-1}$ \\
\hline
\end{tabular}

From the table it can be noticed that the fluorescene maxima shows solvent dependency. In non-polar solvents such as cyclohexane, benzene, chloroform and dichloroethane the $\lambda_{\text {flu max }}$ vary in the order $\mathbf{4}>\mathbf{3}>\mathbf{2}$ while in protic polar and aprotic polar solvents the order of $\boldsymbol{\lambda}_{\text {flumax }}$ is 2>3>4. The above trend can be explained due to the solvationand structural effects. In the absence of solvation, amino group and bigger structure causes emission to occur at longer wavelength while in the polar solvents a small molecule can be effectively solvated and the solvated molecule emits at longer wavelengths. A similar solvent dependent stokes shift is observed in all the compounds. However the quantum yield follows a fixed relationship. In a given solvent the $\mathbf{4}$ is more fluorescence than the compound $\mathbf{3}$ which in turn is more efficient than compond 2. It is known that electron donating group in aromatic compound enhance fluorescence while electron withdrawing groups diminishes by improved non-radioactive decay. The quantum yield of compound 4 vary in between 0.21 and 0.66 , similarly the quantum yield of $\mathbf{3}$ and $\mathbf{2}$ vary in between 0.019 and 0.42 and 0.02 and 0.36 respectively.

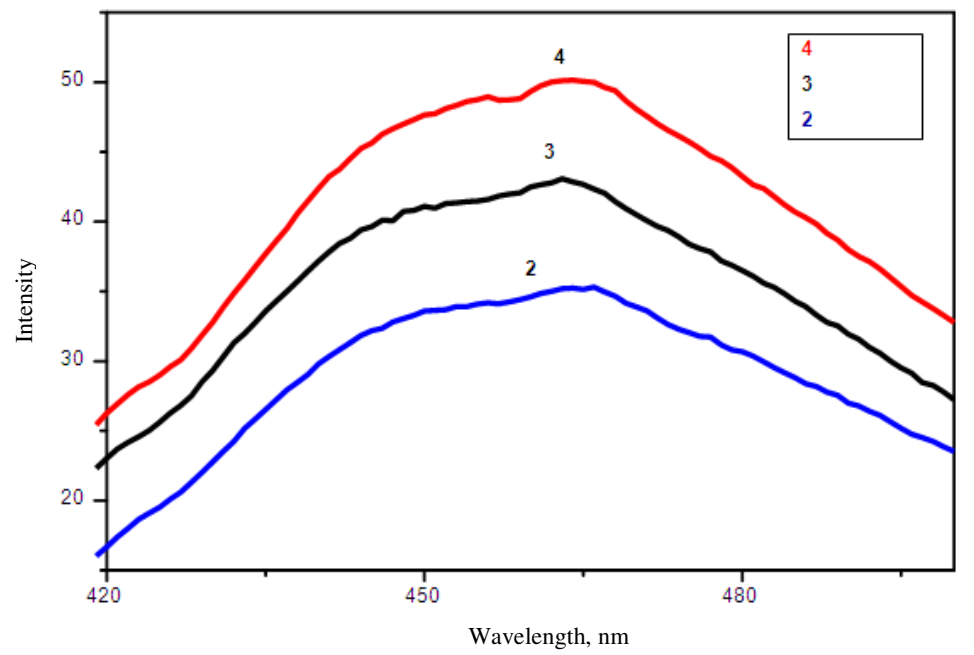

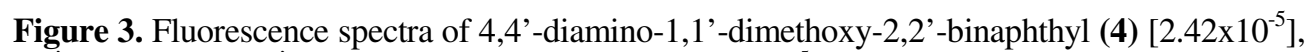
1,1'-dimethoxy $-4,4^{\prime}$-dinitro-2,2'-binaphthyl (3) $\left[4.12 \times 10^{-5}\right]$, and 1-methoxy-4-nitronaphthalene (2) $\left[8.2 \times 10^{-5}\right]$ in DCE. 


\section{Conclusion}

The electronic absorption spectra of 4,4'-diamino-1,1'-dimethoxy-2,2'-binaphthyl have not displayed significant solvatochromism and the absorption maxima follow neither the order of solvent polarity nor substitution dependency. Compounds with electron withdrawing groups have larger fluorescence quantum yields than the compounds with electron donating groups. Among all the solvents investigated, acetonitrile medium causes the emission maxima blue shifted in all the compounds. Compound 2 and 3 with a strong electron withdrawing group showed greater solvatochromism than the remaining compounds. Spectral characteristics are solvent and compound specific. In protic solvents the fluorescence quantum yields are larger. The electronic absorption and emission spectra of these compound show strong solvent dependency. The electronic absorption spectra are influenced by both the electronic and stearic factors. When the nitro group was reduced to amino group, the reduced form is more fluorescent than its more oxygen counterparts.

\section{Acknowledgement}

Author would like to thank the Registrar, Osmania University and University Grant Commission for providing financial support under faculty development program.

\section{References}

1. Sanchez C, Lebeau B, Chaput F and Boilot J P, Adv Mater., 2003, 15(23), 1969-1994; DOI:10.1002/adma.200300389

2. Imahori H, El-khouly M E, Fijitsuka M, Ito O, Sakata $\mathrm{Y}$ and Fukuzumi S, J Phys Chem A. 2001,105(2), 325-332; DOI:10.1021/jp002158b

3. Imahori H, Norieda H, Yamada H, Nishimura Y, Yamazaki I, Sakata $\mathrm{Y}$ and Fukuzumi S, J Am Chem Soc., 2001, 123(1), 100-110; DOI:10.1021/ja002154k

4. Paddon-Row M N, Adv Phys Org Chem., 2003, 38, 1-85; DOI:10.1016/S00653160(03)38001-3

5. Van der Boom T, Hayes R T, Zhao Y,Bushard P J, Weiss E A and Wasielewski M R, J Am Chem Soc., 2002, 124(32), 9582-9590; DOI:10.1021/ja026286k

6. Davis W B, Ratner M A and Wasielewski M R, Chem Phys., 2002, 281(2-3), 333346; DOI:10.1016/S0301-0104(02)00444-5

7. Heinen U, Berthold T, Kothe G, Stavitski E, Galili T, Levanon H, Wiederrecht G and Wasielewski M R, J Phys Chem A. 2002, 106(10), 1933-1937; DOI:10.1021/jp011805b

8. Shaakov S, Galili T, Stavitski E, Levanon H, Lukas A and Wasielewsk M R, J Am Chem Soc., 2003, 125(25), 6563-6572; DOI:10.1021/ja034356x

9. Blank A, Galili T and Levanon H, J Porphyrins Phthalocyanines, 2001, 5(1), 58-66; DOI:10.1002/1099-1409(200101)5:1<58::AID-JPP297>3.0.CO;2-B

10. Berg A, Shuali Z, Asano-Someda M, Levanon H, Fuhs M and Möbius K, J Am Chem Soc., 1999, 121(32), 7433-7434; DOI:10.1021/ja990734f

11. Wasielewski M R, Niemczyk M P, Svec W A and Pewitt E B, J Am Chem Soc., 1985, 107(4), 1080-1082; DOI:10.1021/ja00290a066

12. Ghiggino K P, Clayton A H A, Lawson J M and Paddon-Row M N, New J Chem., 1996, 20(7-8), 853-859.

13. Janssen R A J and Beek W J E, Adv Funct Mater., 2002, 12(8), 519-855; DOI:10.1002/1616-3028(20020805)12:8<519::AID-ADFM519>3.0.CO;2-K 
14. He J, Benkö G, Korodi F,Polivka T, Lomoth R, Akermark B, Sun L, Hagfeldt A and Sundstrom V, J Am Chem Soc., 2002, 124(17), 4922-4932; DOI:10.1021/ja0178012

15. Head N J, Thomas J, Shephard M J, PaddonRow M N, Bell T D M, Carbal N M and Ghiggino K P, J Photochem Photobiol A: Chem., 2000, 133(1-2), 105-114; DOI:10.1016/S1010-6030(00)00215-X

16. Segura M, Sanchez L, de Mendoza J, Martin N and Guldi D M, J Am Chem Soc., 2003, 125(49), 15093-15100; DOI:10.1021/ja036358n

17. Tkachenko N V, Lemmetyinen H, Sonoda J, Ohkubo K, Sato T, Imahori H and Fukuzumi S, J Phys Chem A, 2003, 107(42), 8834-8844; DOI:10.1021/jp035412j

18. Neeraj A, Pabitra K N and Periasamy N, J Chem Sci., 2008, 120(4), 355-362; DOI:10.1007/s12039-008-0059-3

19. Plaza-Medina E F, Rodríguez-Cárdoba W, Morales-Cueto R and Peon J, J Phys Chem A, 2011, 115(5), 577-585; DOI:10.1021/jp109041y

20. Flamini R, Tomasi I, Marrocchi A, Calotti B and Spalletti A J, Photochem Photobiol A: Chem., 2011, 223(2-3), 140-148; DOI:10.1016/j.jphotochem.2011.08.011

21. Megyesi M, Biczók L, Görner H and Miskolczy Z, Chem Phys Lett., 2010, 489(1-3), 59-63; DOI:10.1016/j.cplett.2010.02.050

22. Zugazagoitia J S, Almora-Díaz C X and Peon J, J Phys Chem A., 2008, 112(3), 358365; DOI:10.1021/jp074809a

23. Sojiro Hachiya, Kengo Asai and Gen-ichi Konishi, Tetrahedron Lett., 2013, 54(14), 1839-1841; DOI:10.1016/j.tetlet.2013.01.096

24. Ramchander J, Rameshwar N, Sheshashena Reddy T, Gajula Raju and Ram Reddy A, J Chem Sci., 2014, 126(4), 1063-1074; DOI:10.1007/s12039-014-0677-x

25. Ramchander J, Gajula Raju, Rameshwar N, Sheshashena Reddy T and Ram Reddy A, Spectrochimicaacta Part A: Molec Biomolecular Spectroscopy, 2012, 85(1), 210-216; DOI:10.1016/j.saa.2011.09.062

26. Ramchander J and Ram Reddy A, Indian J Chem., 2011, 50B, 876-878. 